\title{
Effects of Ular Tangga Games on the Development of Locomotor Skills in Elementary School
}

\author{
Udi Sahudi $^{1 \text {,*, Ali Priyono }}{ }^{1}$, Yudha M. Saputra ${ }^{2}$ \\ ${ }^{1}$ Physical Education Study Program, Universitas Majalengka, Majalengka, Indonesia \\ ${ }^{2}$ Sport Education, School of Postgraduate Studies, Universitas Pendidikan Indonesia, Bandung, Indonesia
}

Received April 23, 2021; Revised July 14, 2021; Accepted July 19, 2021

\section{Cite This Paper in the following Citation Styles}

(a): [1] Udi Sahudi, Ali Priyono, Yudha M. Saputra, "Effects of Ular Tangga Games on the Development of Locomotor Skills in Elementary School," International Journal of Human Movement and Sports Sciences, Vol. 9, No. 4A, pp. 119 124, 2021. DOI: 10.13189/saj.2021.091320.

(b): Udi Sahudi, Ali Priyono, Yudha M. Saputra (2021). Effects of Ular Tangga Games on the Development of Locomotor Skills in Elementary School. International Journal of Human Movement and Sports Sciences, 9(4A), 119 124. DOI: $10.13189 /$ saj.2021.091320.

Copyright $\odot 2021$ by authors, all rights reserved. Authors agree that this article remains permanently open access under the terms of the Creative Commons Attribution License 4.0 International License

\begin{abstract}
Locomotor skill has an important role in the implementation of Physical Education learning, especially sports that require moving places or stresses, such as sprinting, long jump, high jump, and other sports. This study aimed to determine the differences in the student locomotor skills before and after the students played the Ular Tangga game. In a quasi-experimental study design, thirty-two $(n=32)$ grade 3 elementary school students (age: mean \pm SD) participated in this study. Findings showed that the t-count value was greater than the t-table value in the initial and final test results (12.155> 2.042). The results showed that the post-test mean score was higher, 8.28, with a higher standard deviation, 9.71. It means that there was a difference in the average score of the student locomotor movement skills before and after playing the Ular Tangga game. The average value and the t-count value was 12.15 . It was due to an increase in student's locomotor movement skills. The application of the Ular Tangga game caused students to move places. Thus, the student movement increased. It concludes that children who play Ular Tangga games will experience better motor skill development and improvement than their peers.
\end{abstract}

Keywords Development, Locomotor Skills, Ular Tangga Games

\section{Introduction}

Basic movement skills are basic patterns of behaviour that can be observed from childhood (1). Basic movement skills in elementary school include three types, namely locomotor, non-locomotor, and manipulation movement skills. The development of fundamental movement skills early in life is essential for building the more complex movement patterns necessary for participation in all kinds of games, physical activities, and sports (2). One of the objectives of implementing Physical Education, Sports, and Health learning is to improve basic movement skills and abilities (3). Gross motor development, an important component of preschool and elementary school Physical Education, is usually divided into phases. In the fundamental movement phase, cognitively and physically normal children aged two to six or seven years progress through the basic, early, and adult stages to acquire skills, such as running, jumping, kicking, throwing, and catching (4). By developing motor skills, children fulfil their desire to move, build their bodies, and increase their attention. In addition, they develop cognition and language skills through learning new terms and discussing them during and after practices.

Increasing gross motor skills in children through play activities is very important, because play activities can be fun activities for children. Children can make spontaneous movements. In a pedagogical approach, something fun can be used as a basic stage for carrying out activities related to children. By playing, like the physical, not at the table and aspects of choice and autonomy (5). Through play activities, children will get used to moving their limbs which will train their flexibility, balance, and body 
coordination. Play activities are also an entertainment for children, so that children do not feel bored in learning that creative ideas will emerge. The psychological character of elementary school students is that they are always active, have a high curiosity, and are interested in games or competitions. Playing is an activity that children really enjoy. In various situations and places, children always take the time to use it as an arena for playing and games.

Playing is one approach in carrying out educational activities for early childhood. Besides having an educational function, playing is also a fun reaction for children because children can channel their tension in a more positive way (6). Through playing, children learn how to use tools, how to develop skills, how to avoid danger, and how to cooperate with other children. The playing method is an activity that can help develop children's creativity and physical motor skills by using strategies, methods/materials, interesting media, and games. Activities that enhance motor physical development can be done through playing with tools or without tools, such as walking, running, jumping, hopping, creeping, and throwing a ball (7). The channelled movements can make children healthier and increase locomotor movements, thus children will increase their self-confidence, independence, cooperation, and intellectual development (8). The conclusion is that a game model is needed in Physical Education at the elementary school level to develop student skills. It is also to make it easier for students to understand the material with high feelings of pleasure and enthusiasm. However, Physical Education teachers rarely update or implement various kinds of varied games that can be useful for improving student basic movement, due to the facilities and capacity of the excessive number of students. Cai Su et al. in the results of their research stated that there were differences in the performance of participants before and after the intervention, they found that the performance of participants in playing the game increased rapidly during the intervention and movement-based games could help improve their performance in terms of motor skills and recognition (9).

In addition, the results of research by Melvin Chung et al. shows that preschool age is an important phase for the acquisition and development of Fundamental Motor Skills (FMS), which have the potential to influence children to participate in games and sports later in life. Therefore, findings about gender differences in Fundamental Motor Skill (FMS) and low locomotor levels, can be carried out with gender-separated games or sports, so that boys and girls can have the same level of Fundamental Motor Skill (FMS) before starting primary school (10). Furthermore, Keith Costello and Joe Warne explained the results of the study that the effect of basic movement skills given for four weeks, 30 minutes per week, can improve Fundamental Motor Skill (FMS) skills for boys and girls aged 8-10 years. The results of this study can be used by teachers as a method for teaching basic motor skills by using different games. It is believed that this intervention is feasible for the school PE curriculum for 8 to 10 year old children so that focused fundamental motor skill literacy becomes a key part of the child education in the future (11).

The game in practice is not only looking for fun, but also looking for victory because there are rules in the game. Basic walking, running, and jumping movements are basic locomotor movements that need to be implemented and developed in elementary schools. Locomotor movement is a type of movement characterized by the movement of the entire body in the process of moving a place or weight from one fulcrum point to another. Balance is the basis condition for being able to perform many locomotor skills and to be able to control objects efficiently (12).

Locomotor movement can be interpreted as movement to move places. Locomotor movement has an important role in the implementation of Physical Education learning, especially sports that require moving places or stresses, such as sprinting, long jump, high jump, and other sports. Locomotor movements taught to elementary school students include walking, running, and jumping. Keep in mind that playing is a child's world, so that children cannot be separated from the world of playing. The gross motor skills are affected by the children's physical activities, which are generally done through a physical game (13). The traditional games could give significant impacts on the gross motor development of the subjects (14).

This study aimed to determine the effect of the Ular Tangga game in developing and improving the locomotor movement skills of elementary school students. In this study, the researchers wanted to see the development process of student locomotor movement skills.

\section{Methods}

\section{Experimental Design}

The method used in this study was a quasi-experimental method. The use of this method was based on the consideration that the implementation of this research learning took place naturally and students did not feel experimented. The situation was hoped to contribute to the level of validity of the research.

The form of quasi-experimental design used was the Time series design. This research design uses only one group, so it does not require a control group (15). Before receiving treatments, the experimental group was first given a pretest, then treated using the Ular Tangga game followed by a posttest.

\section{Participants Selection}

Researchers had previously observed the characteristics 
of Elementary School Grade 3 students. The observation result showed that $75 \%$ of the students were still low in carrying out locomotor movement skills, which means that they were relevant to be involved in the current study. The samples involved in this study were chosen through a total sampling technique. There were 32 elementary school students in Grade 3 as the research samples.

\section{Locomotor Skill Assessments}

In principle, researching is measuring, thus there must be a good measuring tool, namely an assessment rubric. The instrument rubric in this study is presented in Table 1 and Table 2 .

\section{Ular Tangga Intervention}

The use of the Ular Tangga game in learning had the aim of inviting students to learn and play and providing opportunities for children to manipulate, repeat, discover for themselves, explore, practice, and get countless various concepts and understandings. The simple and easy Ular Tangga game is appropriate when applied in learning. This game has many advantages, including students learning to socialize which means they also learn tolerance, attention, and sportsmanship. It also increases activity and causes interactions between teachers and students and students and other students, so that they are able to work well with heterogeneous group members. In addition, this game is a kind of light game, so it does not burden students.

The type of research used was quantitative research. The paired t-test was used to process, analyse, and provide research conclusions. It was also used to find out whether there was a difference in the average locomotor skill before and after students played the Ular Tangga game.

Table 1. Rubric for locomotor skill assessment

\begin{tabular}{|c|c|c|c|}
\hline Locomotor motion & & Indicator & Maximal Score \\
\hline Run & $\begin{array}{l}1 . \\
2 . \\
3 . \\
4 . \\
5 .\end{array}$ & $\begin{array}{l}\text { upright body position } \\
\text { swing the arm against the leg } \\
\text { bent knees } \\
\text { and balance when walking } \\
\text { raise heels while running }\end{array}$ & 5 \\
\hline Jump & $\begin{array}{l}1 . \\
2 . \\
3 . \\
4 . \\
5 .\end{array}$ & $\begin{array}{l}\text { unused leg as a prefix to resist } \\
\text { raise at knee height in a bent state } \\
\text { do the repulsion with one leg } \\
\text { arms bent and swung forward to generate force } \\
\text { the position of the body is lifted up when landing }\end{array}$ & 5 \\
\hline Walk & $\begin{array}{l}1 . \\
2 . \\
3 . \\
4 . \\
5 .\end{array}$ & $\begin{array}{l}\text { upright body position } \\
\text { swing the arm against the leg } \\
\text { knees not bent } \\
\text { and balance when walking } \\
\text { footstool is on the soles of the feet }\end{array}$ & 5 \\
\hline
\end{tabular}

Table 2. Assessment format

\begin{tabular}{|c|c|c|c|c|c|c|c|c|c|c|c|c|c|c|c|c|c|}
\hline \multirow{2}{*}{ No } & \multirow{2}{*}{ Name } & \multicolumn{5}{|c|}{ Run } & \multicolumn{5}{|c|}{ Jump } & \multicolumn{5}{|c|}{ Walk } & \multirow{2}{*}{$\begin{array}{l}\text { Total } \\
\text { score } \\
\end{array}$} \\
\hline & & 1 & 2 & 3 & 4 & 5 & 1 & 2 & 3 & 4 & 5 & 1 & 2 & 3 & 4 & 5 & \\
\hline \multicolumn{18}{|l|}{1} \\
\hline \multicolumn{18}{|l|}{2} \\
\hline \multicolumn{18}{|l|}{3} \\
\hline \multicolumn{18}{|l|}{4} \\
\hline \multicolumn{18}{|l|}{5} \\
\hline \multicolumn{18}{|c|}{$\begin{array}{l}\text { Description of the score obtained: } \\
\text { - } \quad \text { Value 1: if it fulfils } 1 \text { assessed aspect } \\
\text { - } \quad \text { Value 2: if it fulfils the } 2 \text { assessed aspects } \\
\text { - Value 3: if it fulfils the } 3 \text { assessed aspects } \\
\text { - Value 4: if it fulfils the } 4 \text { assessed aspects } \\
\text { - Value 5: if it fulfils the } 5 \text { assessed aspects } \\
\text { Table 3. Results of Research Data Analysis }\end{array}$} \\
\hline & Test & & & Mi & Max & & Me & & & Me & Diff & ence & & & & & $\mathbf{t}$ \\
\hline & $\begin{array}{c}\text { Pre-test } \\
\text { Post-Test }\end{array}$ & & & & & & $\begin{array}{l}8, \\
9,\end{array}$ & & & & 1,43 & & & & & & 12,55 \\
\hline
\end{tabular}




\section{Results}

The data analysis results of this study are presented in Table 3.

Table 3 shows that from 32 students, the minimum score of the student's locomotor skills during the pre-test and post-test was different. The minimum pre-test score was 6 , while the maximum score was 11 . The results of the post-test obtained a minimum score of 7 and a maximum score of 13 . The result of the mean post-test score was greater, 8.28 , with a higher standard deviation, 9.71. It shows that there was an increase in locomotor movement skills from the results of the initial and final tests. The mean increased 1.43. The obtained data show that the t-count value was greater than the t-table value in the initial and final test results, 12.155> 2.042. This means that there is a difference in the mean score of student locomotor skills before and after playing the Ular Tangga game.

The improvement of student locomotor skills in this study can be seen in Figure 1.

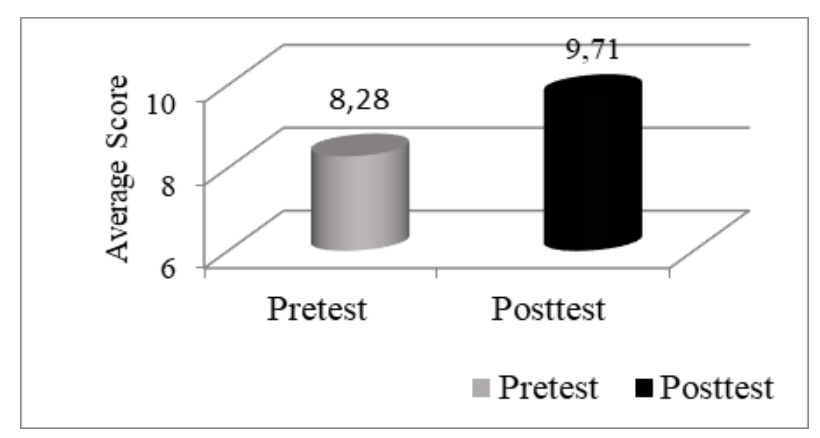

Figure 1. Graphics Improved Student Locomotor Skills

The increase in locomotor skills from the results of the initial test (8.28) and final test (9.71) is 1.43 .

\section{Discussions}

The results of this study indicate that Ular Tangga games can have a significant effect on the development of locomotor skills. The Ular Tangga game provides many chances to deliver and teach each locomotor skill separately, one by one, and thus reactivate the children over and over again. Teaching every locomotor skill individually in this game would give children plenty of opportunities to repeat the movements. The time when children have to move, play, and engage in activities that involve balance of motion and manipulation can help students develop body awareness and motor skills (16). It can help students to more accurately replicate the movement of the desired complex motor skills as expected in the desired model in the future. This creates a standard for each child to repeat the same movements. It can also be assumed that the consistent repetition of critical elements of locomotor skills presented in different movement patterns in video content may have improved children movement skills (14). The development of motor skills that have been carried out so far is important as the basis needed to build children skills in the future, so that they become physically active adults with motor skills that can be adapted to different environments (17). Basic gross motor skills are important in daily existence. Basic gross motor skills are movements performed with large muscles that allow the child to move in a variety of ways, such as running and jumping. For children, gross motor skills are important for exploring the environment, controlling the body, manipulating objects, and stabilizing oneself. At this time, children begin to develop gross motor skills called fundamental motor skills (FMS), which consist of locomotor skills and object control skills. Locomotor skills involve moving the body through space and include the ability to run, jump, and slide. Object control skills include throwing, catching, bouncing, and kicking (18). Traditional games could also help introduce values or norms that are upheld in society, as well as be beneficial for the affective and motor development because it involves a lot of movement and uses cognition in managing strategy (19). The results of this study help students develop basic locomotor and manipulative movements. Basic locomotor and manipulative movements are the basic movements needed to master advanced skills such as various skills needed in other sports. Therefore, by developing the basic movements of students, Physical Education teachers help these students to be able to more easily master a sport they are interested in later when they continue their education at the next level. Motor skills can be useful for a person's life and career in various fields of life that are useful according to their talents, tendencies, and potential (20).

The findings, in relation to the significant improvement of jumping and running shown by students from pretest to posttest, are also interesting. This is because it has the potential to speak to the "generalization" and "transference" processes. Over the years, researchers have discussed the concepts of generalization and transference as they relate to the acquisition of motor skills through the practice of motor patterns that are similar to or close to the desired skill (21). It should be noted, however, that this study did not formally evaluate student's psychological experiences (e.g. enjoyment or motivation, etc.), but instead focused on outcomes (improvement of student locomotor skills). Further study can capture the psychological element to further refine the feedback and instruction delivered to students.

This research had been attempted as much as possible to obtain good results, but in reality there were still shortcomings caused by limitations, including that the variables studied only described gross motor skills, such as running, jumping, and walking.

Future researchers are expected to be able to conduct further research regarding the application of learning methods in improving locomotor movement abilities and repeated research that can involve a larger number of 
samples to solve problems well and assess other aspects, such as jumping or walking backwards.

\section{Conclusion}

The Ular Tangga game has a significant effect on the development of children's basic movement skills. It concludes that the child who does a lot of movements by playing at elementary school age is more likely to develop and improve a student's motor skills further than their peers. Further research is needed to investigate influential variables on the locomotor skill development other than Ular Tangga games in elementary school students.

\section{Acknowledgement}

I would like to thank Professor Saputra for his useful guidance, support, and criticism in conducting the research, as well as for all who have supported me in conducting the research. No grants were used to support the research implementation.

\section{REFERENCES}

[1] O' Brien W, Belton S, Issartel J. The relationship between adolescents' physical activity, fundamental movement skills and weight status. J Sports Sci. 2016;34(12):1159-67.

[2] Trost SG, Brookes DSK. Effectiveness of a novel digital application to promote fundamental movement skills in 3to 6-year-old children: A randomized controlled trial. J Sports Sci [Internet]. 2020;00(00):1-7. Available from: https://doi.org/10.1080/02640414.2020.1826657

[3] Badan Standar Nasional Pendidikan. Peraturan Badan Standar Nasional Pendidikan. 2017;1-9.

[4] Derri V, Tsapakidou A, Zachopoulou E, Kioumourtzoglou E. Effect of a Music and Movement Programme on Development of Locomotor Skills by Children 4 to 6 Years of Age. Eur J Phys Educ. 2001;6(1):16-25.

[5] Wainwright N, Goodway J, John A, Thomas K, Piper K, Williams K, et al. Developing children's motor skills in the Foundation Phase in Wales to support physical literacy. Educ 3-13 [Internet]. 2020;48(5):565-79. Available from: https://doi.org/10.1080/03004279.2019.1633374

[6] Lenoir M, Savelsbergh GJP, Musch E, Thiery E, Uyttenhove J, Janssens M. Intercepting moving objects during self-motion: Effects of environmental changes. Res Q Exerc Sport. 1999;70(4):349-60.

[7] Chatzopoulos D, Foka E, Doganis G, Lykesas G, Nikodelis T. Effects of analogy learning on locomotor skills and balance of preschool children. Early Child Dev Care [Internet]. 2020;0(0):1-9. Available from: https://doi.org/10.1080/03004430.2020.1739029
[8] Ruitenberg MFL, De Dios YE, Gadd NE, Wood SJ, Reuter-Lorenz PA, Kofman I, et al. Multi-day Adaptation and Savings in Manual and Locomotor Tasks. J Mot Behav. 2018;50(5):517-27.

[9] Cai S, Zhu G, Wu YT, Liu E, Hu X. A case study of gesture-based games in enhancing the fine motor skills and recognition of children with autism. Interact Learn Environ [Internet]. 2018;26(8):1039-52. Available from: https://doi.org/10.1080/10494820.2018.1437048

[10] Melvin Chung HL, Cheah WL, Hazmi H. Fundamental motor skill among preschool children in rural of Kuching, Sarawak. Early Child Dev Care [Internet]. 2019;0(0):1-13. Available from: https://doi.org/10.1080/03004430.2019.16 58088

[11] Costello K, Warne J. A four-week fundamental motor skill intervention improves motor skills in eight to 10-year-old Irish primary school children. Cogent Soc Sci [Internet]. 2020;6(1). Available from: https://doi.org/10.1080/233118 86.2020 .1724065

[12] Kelly L, O’Connor S, Harrison AJ, Ní Chéilleachair NJ. Effects of an 8-week school-based intervention programme on Irish school children's fundamental movement skills. Phys Educ Sport Pedagog [Internet]. 2020;0(0):1-20. Available from: https://doi.org/10.1080/17408989.2020.18 34526

[13] Hayati HS, Myrnawati C, Asmawi M. Effect of traditional games, learning motivation and learning style on childhood gross motor skills. Int $\mathrm{J}$ Educ Res. 2017;5(7):53-66.

[14] Abdullah B, Amri S. Effects of Traditional Games on Age Equivalent Scores of Locomotor and Manipulative Skills among Early Stage School Children. Int J Acad Res Bus Soc Sci. 2018;8(12):134-45.

[15] Sugiyono. Metode Penelitian Pendidikan (Pendekatan Kuatintatif, kualitatif dan R\&D). Manajemen Pelayanan Umum Di Indonesia. Bandung: Alfabeta; 2010. 114-115 p.

[16] Mehta AK, Halder S, Khanna N, Tandon OP, Sharma KK. The effect of the essential oil of Eugenia caryophyllata in animal models of depression and locomotor activity. Nutr Neurosci. 2013;16(5):233-8.

[17] Donenberg JG, Fetters L, Johnson R. The effects of locomotor training in children with spinal cord injury: a systematic review. Dev Neurorehabil [Internet]. 2019;22(4):272-87. Available from: https://doi.org/10.108 $0 / 17518423.2018 .1487474$

[18] Jahagirdar I, Venditti LA, Duncan A, Reed N, Fleming S. Exploring the relationship between participation in a structured sports program and development of gross motor skills in children ages 3 to 6 years. J Occup Ther Sch Early Interv [Internet]. 2017;10(3):203-12. Available from: https://doi.org/10.1080/19411243.2017.1325816

[19] Savitri Widia, Agustini, Astiti, Suarya H. Stimulation, Traditional Games as Alternative Activities for Children. JPAI, J Psychol Instr. 2020;04(01):1-9

[20] Sahudi U, Nurhayati M. Penerapan Metode Pembelajaran dengan Permainan Bola Gantung Berangka untuk Meningkatkan Gerak Dasar Anak Usia Dini di Kecamatan Panyingkiran Kabupaten Majalengka. Pros Semin Nas 
Pendidik Jasm dan Olahraga [Internet]. 2018;2:163-72.

Available from: https://scholar.google.comhttps//scholar.g oogle.com/scholar?oi=bibs\&cluster=\&btnI=1\&hl=en
[21] Davids, K., Button, C., \& Bennett, S. A. Dynamics of skill acquisition constraints-led approach. Champaign, IL: Human Kinetics. 2008. 